\title{
The Biographical Illumination: A Bourdieusian Analysis of the Role of Theory in Educational Research
}

\author{
by Ciaran Thomas Burke \\ Queen's University Belfast
}

\author{
Sociological Research Online, 16 (2) 9 \\ <http://www. socresonline.org.uk/16/2/9.html> \\ $10.5153 /$ sro. 2325
}

Received: 12 Oct 2010 Accepted: 14 Mar 2011 Published: 31 May 2011

\begin{abstract}
The intention of this paper is to serve as a reflexive comment as to my ongoing empirical processes and epistemological position concerning research on university graduates' aspirations and expectations of graduate employment. This paper will illustrate the inevitable role of social theory in empirical research, and from a Bourdieusian position, consider the use of theory in creating a break with common sense, the danger of replacing common sense with learned bias, and processes that may aid to avoid this problematic issue. Using educational research as a tangible basis, this paper will discuss the empirical application of the habitus in creating a break with common sense, whilst not losing itself to social theory. However, in an effort to depart from simply offering a comment on the need for the application of theory in educational research, this paper intends to demonstrate how the neo-positivist biographical narrative interview method can, contrary to Bourdieu's (1987) comments, illuminate the habitus, offering an opportunity for its empirical application in educational research and also for the wider academy.
\end{abstract}

\section{Keywords: Habitus; Biographical Interview; Epistemological Break; Educational Research; Bourdieu}

\section{Theory: an unavoidable necessity}

1.1 The relationship between theory and empiricism is one that we cannot and should not avoid. Miller (2000) argues that, to conduct research, we need to abandon the concept of an autonomous agent removed from society, and understand how they relate to the society around them. This should be extended to how we understand our role and position as researchers. Researchers and academics are highly educated; they relate to the academic society around them, they do not come to research devoid of theoretical bias or concepts. Hammersley (2008: 22) charges qualitative researchers with an 'offensive failing', created through a preoccupation and feeling of superiority from the supposed ability to understand or appreciate an individual's perspective. Hammersley (2008: 23-28) explains that qualitative researchers criticised the presupposed nature of quantitative surveys, and the overarching presence of the researcher's values in the research process. A similar critique was offered towards social theorists, as the qualitative school understood the categories social theorists create, as reifications abstracted from the individual's perspective. However, Hammersley contends that qualitative research involves not only, the application of theoretical categories, but, empirical inquiry will be reduced, or narrowed, by the nature of the problématique, 'they cannot escape doing so' (Hammersley 2008: 44, emphasis in original). Carr (2000) offering a discussion of two essays from Gouldner in the 1960s, concerning the issue of value free sociology, tells us, that for Gouldner, "value free" sociology was a myth. Gouldner understood partisanship in sociology as a healthy predisposition and not an obstacle towards objectivity, as conceptual objectivity requires the researcher to firstly understand who they are, and where their partisan biases lie.

1.2 It is from this position that we can see the application of purely inductive research, absent of theory or pre-constructed/considered concepts, is an untenable goal, to misrecognise such a goal, can be damaging to the research process. Bourdieu et al. advise their audience to observe caution towards this, at times, attractive approach:

To refuse the explicit formulation of a body of hypotheses based on a theory amounts to accepting presuppositions that are nothing other than the pre-notions of spontaneous sociology and ideology, i.e. the questions and concepts that one has as a social subject 
1.3 Bourdieu et al. (1991) discuss the problematic image of objective data or exploratory research. The problem stems from the understanding of the term experiment, or the hypothesis, exploratory or inductive research suggests a lack or an absence of theory. Bourdieu et al. (1991) appear quite hostile to the "neutral researcher" - they contend that analysis of research cannot simply be a recital of a transcript, but an interpretation of their words, nor can an interview or questionnaire be completely comprised without theoretical consideration. Wacquant (1993:35) explains that, for Bourdieu every aspect of research, whether it be the scale of measurement, the decision of which item to include in a questionnaire, to coding decisions, are all practices influenced by theory. This is an inescapable process.

1.4 This position, however, does not mean that we must reject the rich data that inductive approaches such as grounded theory have provided. Heath and Cowley (2004) question the purely inductive nature of grounded theory, discussing the rift between the original architects, Glaser and Strauss (1967), in relation to the place or role of pre-conceptions or hypotheses in a research context. The authors explain that Strauss along with Corbin developed an appreciation, or form, of grounded theory where previous literature or theory can help sensitise the data, rather than contaminate it.

1.5 It is clear that theory plays a part in every aspect of the data collection. Stemming from this realisation we need to decide how to utilise this relationship, if we were to simply ignore the inevitable role of theory, we would have no way of accounting for it. From this position, a grounded approach, that accepts the presence of social theory, is a more useful and, indeed, pragmatic form of data collection.

\section{Common Knowledge: the challenge to sociology}

2.1 Not only is the relationship between social theory and empirical research inevitable, it is also crucial. Mills (1959) in The Sociological Imagination explains quite clearly that to think sociologically is to critically question the relationship between structure (society) and agency (biography). Mills discusses the difficulty individuals experience when trying to understand these relations. He discusses individuals lacking: 'a quality of mind' (1959: 4) pointing towards the untrained mind or common sense understanding. It is only through the gaining of certain tools and experiencing modes of thought that this sociological imagination can begin to establish itself. Social theory is a central component towards developing the ability to critically assess the relationship between structure and agency. This sentiment can be clearly seen in Ball's writing, as he comments, '[theory] provides a language or rigour and irony rather than contingency' (1995: 266). In terms of practical research, theory gives us a direction, accepting this relationship gives researchers the opportunity to enhance their research through its application.

2.2 A key issue for social researchers is that, whilst they are studying the social world, they are also social actors. As social actors, they have been socialised to accept certain social norms or common sense understandings of relations. Bourdieu et al. (1991) warn their readers of the dangers of being too comfortable with the social world in which they work. A tacit understanding, whilst helpful, is an obstacle to overcome. They write:

Epistemological vigilance is particularly necessary in the social sciences, where the separation between everyday opinion and scientific discourse is more blurred than elsewhere ... for the sociologist, familiarity with his social universe is the epistemological obstacle par excellence, because it continuously produces fictitious conceptions or systematisations and, at the same time, the conditions of their credibility. The sociologist's struggle with spontaneous sociology is never finally won, and he must conduct unending polemics against the blinding self-evidences which all too easily provide the illusion of immediate knowledge and its insuperable wealth. (1991: 13)

2.3 Bourdieu et al. comment that what is crucial for effective research is an epistemological break with preconceptions or common sense. These preconceptions are so deeply embedded within our conscience, that we need to be overtly objective, to create a break. A critically theoretical approach to the study of our society can aid researchers in creating this break with common understanding or common sense.

\section{Theory and Empiricism: against a binary definition}

3.1 For Bourdieu et al. (1991: 29-30), theory should not be an autonomous practice; its purpose is to provide the means of a break with preconceptions and also to provide the means to a solution of contradictions resulting from research. The crucial point being, that theory and empiricism should be understood to be in a working partnership. Mills was quite scathing towards the separate application of grand theory or abstracted empiricism. He understands grand theory to be: 'drunk on syntax, blind to semantics' (1959: 34), whilst abstracted empiricism is conducted: 'within the curiously self-imposed limitations of their arbitrary epistemology...' (1959: 55). For Mills, what is necessary is a combination that allows grand theory to appreciate grounded conditions, and empiricism to look outward. Bourdieu et al., echoing Mills' comments, warn their readers, if we do not, we:

[T]rap research in an all-or-nothing dilemma in which it has to choose between pointillist hyper-empiricism and a universal general theory of the social system. (1991: 30)

3.2 Wacquant (1992: 26-35) comments, that Bourdieu was concerned with returning theory to an empirical context, allowing it to generate knowledge. Wacquant continues with his discussion, explaining that Bourdieu had very little sympathy or time for self-contained theory that had no illusions of being embraced by empiricism. Bourdieu saw method as 'polythetic', not in the sense, Wacquant explains, as nonchalance or an arbitrary approach to methodology, but one which is reflexive to the problématique. Empirical methodology should not be understood as an insentient technique, but rather, as an active and dynamic 
aspect of the research. This reflexivity towards the problématique can be, if not generated, at least aided by theory, therefore creating more appropriate data collection strategies. This partnership of theory and method should not be understood as a binary or dualist relationship, Wacquant explains:

\section{[Bourdieu] does not seek to connect theoretical and empirical work in a tighter manner but to cause them to interpenetrate each other entirely (1992: 34-35, emphasis in original)}

3.3 The acceptance of the presence of theory, also reminds us that we need to safeguard against theoretical biases that may affect a researcher's analysis. As discussed above, Bourdieu along with his colleagues argue for the need to break with common sense, provided by the epistemological break (Bourdieu et al. 1991) or radical doubt (Bourdieu and Wacquant 1992). This was to provide a safeguarding against lay knowledge or presuppositions. However, what is necessary along with this is to provide a safeguard against our theoretical presuppositions. Bourdieu (1992: 248-253), discusses the 'double bind' that social researchers find themselves wedged between. He explains, as researchers we must employ academic tools to create the break from common sense, however, the danger lies in simply replacing lay common sense with academic or learned common sense. For Bourdieu, the key to escaping this 'double bind', is through, constant, critical reflection, what Bourdieu describes as: 'a genuine conversion, a metanoia, a mental revolution, a transformation of one's whole vision of the social world' (1992: 251). It is clear that a second break is required, a break with learned common sense, or a radical doubt towards theory.

3.4 The position towards creating a system of oversight for the influence of theory in research has strongly been advocated by feminist researchers. Du Bois (1983: 106) contends that all social theory up until now has been a theory created by, and for the advancement of, men. She continues to argue that, even when women have been the subject of study, the questions asked and the answers interpreted have been carried out in a manner that reinforces the phallocentric culture of social science. Similarly, Oakley (1981) has argued, sociology has negated to view the world from a feminist perspective, ignoring the importance of social interaction in favour of objective observations. Feminist authors are attempting to break away from not only the (patriarchal) common sense of society, but, as they see it, the patriarchal learned common sense of social theory.

3.5 Oakley (1981) questions whether "traditional" research practices support a masculine paradigm. She comments that "traditional" interviewing techniques leave feminist researchers wanting, as their goal is to understand the subjective experience of women. She argues there is a 'lack of fit' between traditional theory and practice in feminist research. Du Bois (1983: 108) argues that, to challenge this masculine dominated science, a 'women's centred scholarship' is required to understand women's lives in their own terms and not to understand them through a masculine gaze. Klein suggests that a feminist methodology can "free ourselves from paralysing stereotypes" (1983: 95).

3.6 Du Bois (1983: 109-110) does not advocate for a specific feminist scientific methodology as such, but a feminist consideration, or rationale, for the methods chosen in research. She continues to argue that the strength in a feminist research lies in the beginning of the process. Before a theory is generated, she suggests, a researcher must observe their respondents. It is here that she advocates a researcher must see women as they are and not through a pre-constructed, masculine lens. Focusing on women, provides an opportunity to break away from masculine dominated, learned common sense. In order to do this, Du Bois argues, researchers require: 'methods of inquiry that open up our seeing and our thinking, our conceptual frameworks, to new perceptions that actually derive from women's experience' (emphasis in original, 1983: 110). Understanding women through their own experience and using their own words and definitions, Du Bois concludes, is the first step in creating a grounded theory of women. Deem (2002) discusses the continuing use of feminist methodology in empirical research. She illustrates her point with reference to Wajcman's (1998) work on men and women's experiences as senior managers in multinational companies, commenting that Wajcman's findings : 'breaks new ground in the field' (Wajcman 2002: 842). Wajcman reported that, while the style of management was similar for both men and women, her respondents differed in terms of their experiences of the organisation.

3.7 Stanley and Wise (1990) discuss the complexities and conflicts within "feminist methodology", voicing concern that the feminist researcher replaces the patriarch in the dominant role over women and offering approaches to address this issue. This paper is perhaps not the time to offer a protracted discussion on the merits and issues surrounding "feminist methodology". However, Hammersley's (1992) somewhat critical comments towards "feminist methodology" do warrant consideration. Hammersley (1992: 192) argues the attempt to focus on a respondent's experience, their interpretations, over an objective scientific method that assumes social norms, is not only practiced within the feminist discipline. Hammersley continues his discussion, displaying reluctance towards primarily relying on a respondent's experience. $\mathrm{He}$ suggests that in practice few qualitative (including feminist) researchers, in an effort to escape or question social/learned norms, would conduct research in such a way.

3.8 The break with learned common sense can be found in an appreciation of the interpenetrative relationship between theory and method. The interpenetrative relationship creates something new and requires both our theoretical heritage and our empirical results to question each other, creating an opportunity for reflexivity. A theoretically influenced grounded approach would allow theory to have a role in the empirical process, but create an opportunity to display findings that make us question or re-evaluate our theoretical position. This can be seen as a more abstract form of Mills' (1959) advice in the appendix to The Sociological Imagination. Mills advises his readers, in a bid to stimulate the imagination, to empty their files onto the ground and sift through, looking for connections between processes or concepts that they would not have entertained beforehand. This forcing of new concepts and questioning our theoretical position is crucial: 
(impensé) is to condemn oneself to be nothing more than the instrument of that which one claims to think. (Bourdieu and Wacquant 1992: 238)

\section{The Habitus in Educational Research: redundant or resurgent?}

4.1 Bourdieu's (1977) habitus model is understood to be comprised of norms, values and dispositions. The dispositions that comprise the habitus interact with forms of capital: economic, social and cultural (Bourdieu 2004). It is the relationship between the habitus and these different levels of capital which provides an understanding of practice. The relationship between the habitus and capital should be observed in a contextual field. In a visual form, Bourdieu's application of these tools, or concepts, can be understood as: '[(habitus) (capital)] + field = practice' (Bourdieu 1984: 101).

4.2 For Wacquant (1993), it is the habitus that allows Bourdieu to break out of the binary structure/agency debate by addressing the interdependent relationship between objective and subjective elements of practice. The habitus, and in turn Bourdieu's theory of practice, has been heavily criticised, certainly not least by Jenkins (2002). Jenkins understands Bourdieu as a structural determinist, unable to do away with the iron cage, reducing agency to an afterthought.

4.3 In the field of educational research, Bourdieu has produced a number of influential works; the role of a priori capital in the higher education system in Changes in Social Structure and Changes in Demand for Education, with Boltanski (1978), the social reproduction of inequality through the educational system in Reproduction in Education, Society and Culture, with Passeron (1990) and academic culture as a field of power in French higher education in Homo Academicus (1988). Bourdieu and the use of his concepts in educational research has been criticised in the past. Tooley and Darby (1998, cited in Nash 1999), contend that for a progressive and modern understanding of the educational process we must abandon such grand thinkers as Bourdieu, as their comments have become outdated. However, Nash (1999: 185), in reaction to Tooley and Darby's comments, argues that the role of sociology in educational research is to question processes and offer explanations where possible. Nash does not fawn to Bourdieu's comments; nor does he suggest that Bourdieu is capable of giving "answers" to these questions. However, he concedes that Bourdieu's comments make us constantly question and reflect on our own positions: 'without concepts- the tools of thought- we will not make much progress' (1999: 185). Robbins (1998) suggests a key reason for the hostile reception of Bourdieu's work came from a misconception of the meaning of his writing, both in terms of the philosophy that served as the foundation of his work, and also, the philosophy of science which greatly influenced his methodological approaches.

4.4 The work of Diane Reay and colleagues, has greatly contributed to the progression and application of Bourdieu's concepts in educational research within the U.K. These studies have adopted a Bourdieusian approach when looking at, the role of Mother's in primary school education (Reay 1998), classed nature of attitudes or expectations of progression into higher education (Reay et al. 2005) and experiences of working class students in various higher education institutions and their ability to "fit in" (Reay et al. 2010). However, Reay (2004), is cautious of the over use of the habitus, understanding it, at times, to be used as a gloss - a casual exploitation of a highly complex theoretical concept. Reay (2004: 434) argues the habitus should be seen as permeable; it reacts to the context of its surroundings. It is the permeability of the habitus that provides a fuller or more nuanced application, rather than a top-down gloss, as the permeable habitus forces us to recognise the role of agency.

4.5 Reay's permeable habitus can be extended to its use as an empirical tool. Reay (2004: 439) explains that Bourdieu intended the habitus to be applied in an empirical context, as it would theoretically - as a bridge between structure and agency or the objective and the subjective. Reay tells us, Bourdieu understood the relationship between the habitus and empiricism to be nonlinear, therefore appreciating the relationship between the research subject and the research context, and attempting to understand how they work in partnership. It is the permeable nature of the habitus that increases the opportunity for an interpenetrative relationship between theory and empiricism. The permeable character of the habitus, removes or lessens the image of a rigid, structurally deterministic concept, the permeable habitus offers empirical data a greater opportunity to move through it.

4.6 Reay (2004) contends, an appropriate employment of the habitus, would see it working with the data rather than above it. It is through this empirical application, that we may observe the habitus' dynamic and reflexive qualities. This theoretically grounded form of data collection and analysis provides the context for the application of theory therefore providing an opportunity to create an epistemological break, however, it forces researchers to reflect on the relationship between their data and their theory, rather than applying the habitus in a top-down approach, acting as a safeguard or providing a radical doubt against theoretical bias. It is the reflexive process, brought about through the interpenetrative relationship between theory and empiricism, which can create opportunities for progressive understandings. The continuing use of a habitus model, crucially, helps to maintain an appreciation of structural constraints. Ball et al. (2000) and Reay (2000) are critical towards the agentic individualisation concept or, the 'triumph of individualism', as it creates the facade of free agents, who are solely responsible for their choices, choices which they are not free to make, but whose consequences they must face.

\section{Biographical Illusion or Illumination?}

5.1 For the remainder of this paper, I intend to offer a discussion concerning the empirical relationship between the habitus and the biographical interview, in an attempt to address the epistemological challenge as set by Bourdieu. Appreciating the habitus can be a complicated endeavour, as dispositions, values and norms are often so subtle that they can be difficult to measure; as is the dynamic or fluid relationship between structure and agency. Bourdieu suggests that one approach would be to look for repetition, he writes, 'practical identity reveals itself to intuition only in the inexhaustible series of its successive manifestations' (Bourdieu 1987: 3). An ideal approach, and one briefly discussed by Lahire (2003), would 
be a longitudinal ethnographic study. However, time constraints and limited funding force researchers to look for alternative, yet appropriate, forms of data collection that appreciate the relationship between structure and agency and create the opportunity for empirical reflection.

5.2 Holloway and Jefferson (2000: 168) argue against a detached, or fragmented, post-modern understanding of reality and for the need and existence of a tangible "baseline". The biographical approach, the process of telling one's life hi/story in a research situation, is seen as an attempt to bind structure and agency. For an appropriate understanding of biography, we, as researchers, need to place it in the context of structure: 'these three - biography, history, society - are the coordinate points of the proper study of man' (Mills 1959: 143). It is from understanding both structure and agency that one can begin to understand the influence of structure, individual strategies and the influence that experience has towards agency. Because of its depth and richness of data, researchers can look at these tacit, and often hidden, processes of agency in how they relate to structure and how, perhaps, they work against or outside the structure.

5.3 While many authors would use biographical research methods when looking at a major event in history, Elliott (2005: 305) suggests that biographical research can be used to appreciate everyday life. Segert and Zierke (2000: 241), when studying the metamorphosis of habitus amongst East Germans, argue that individuals collect and compile experiences throughout their lives. The influence and effect of these experiences are not necessarily immediate under certain new circumstances these experiences may play a new or renewed role in their actions. Miller et al. explain:

One of the goals of sociological research is to sensitise the observer to that which is usually unremarked - the taken-for-granted everyday behaviours that "hide in plain view." (2005: 113).

5.4 These comments concerning the need for an appreciation of both structure and agency point to the relationship between the habitus and the biographical method. As the habitus can be understood to be permeable, researchers need to be able to look at every day events; no longer life changing events. Experiences may have a cumulative effect on practice, therefore an empirical strategy that can offer an account of trajectories through life hi/stories is required.

5.5 Bourdieu (1987) could be seen as quite critical towards biographical research, as he understood biography to be too agentic. Bourdieu writes, when recording and analysing a life history, the structural influence on the life history must be taken into consideration. If researchers do not, Bourdieu suggests this is:

[N]early as absurd as trying to make sense out of a subway route without taking into account the network structure, that is the matrix of objective relations between different stations.

(1987: 6)

5.6 The form of biography that Bourdieu alludes to in the Biographical Illusion (1987) could be better described as autobiography. He was concerned with applying a form of biography that did not take account of the structure. His intolerance or mistrust towards the concept of "biography" is evident in the introduction to Sketch for a Self Analysis, where he writes, 'this is not an autobiography' (2007). However, the form of biography, as discussed above, is supportive of Bourdieu's theoretical project. Grenfell and James (1998: 10) explain Bourdieu's theory of practice, was concerned primarily, with creating an approach that was objective in its understanding of the structures role in social phenomena, but also respectful of the subjectivity of an individual's actions. The biographical interview looks at an individual's life hi/story, however, it understands the life hi/story not as an autonomous phenomenon untouched by society, but rather it appreciates it as existing within the structure and affected by history.

\section{Biographical Narrative Interview Method: creating the break}

6.1 The biographical perspective has had a long tradition, Miller (2000) and Merrill and West (2009) offer a chronological account of its development, from its roots in Thomas and Znaniecki's The Polish Peasant, to its increasing popularity in the Chicago school, to its re-emergence in Europe through the work of Bertaux and Kohli, there is the ever increasing application of biographical research. As with any method, there are a number of different approaches to the biographical interview. Erben (1998) and Atkinson (1998) provide overviews of the general research process, and offer a discussion on the logic of adopting such an approach. However, it is the specific mechanics of the biographical narrative interview method (Rosenthal 2003; 2005) most notably attributed to Fritz Schütze (1992; 2008), or what is, perhaps problematically, known as the "German school" (Apitzsch and Inowlocki: 2005), that provides an opportunity for a break with common sense and provide a radical doubt towards learned bias, extending the Bourdieusian nature of biographical research beyond an appreciation of structure and agency.

6.2 It would be prudent to briefly discuss the empirical mechanics of the interview, as Mills comments:

There is of course much generous comment in all schools of social science about the blindness of empirical data without theory and the emptiness of theory without data. But we do better to examine the practice and its results, as I am trying to do here, than the philosophical embroidery. (1959: 66)

6.3 The biographical interview is primarily concerned towards constructing an understanding of a respondent's life hi/story. The "traditional" biographical narrative interview (Rosenthal 2003; 2005) is comprised of three sub-sessions. The first sub-session, is solely interested in the initial, or main, narration. It is here that the respondent is asked to tell their life hi/story. During this phase of the interview, the researcher is required to make as little verbal and physical (gestures) input as possible so as to limit the extent of reflexivity. The second sub-session of the interview is generally conducted in the same sitting. The interviewer can ask for greater clarification or more information concerning topics or areas that the 
respondent has discussed. The interviewer can only ask questions addressing areas that the respondent has explicitly discussed - and the order of the questions must follow the order of the narration, the questions must be phrased using the language or terms the respondent used. This is to preserve the gestalt of the life hi/story. The third sub-session generally takes place at a later stage. In the interim, the interviewer conducts a preliminary analysis of the first two sub-sessions. The third sub-session is formed through reflection of the preliminary results. It is in this phase that the interviewer is afforded a greater deal of flexibility. The third sub-session offers an opportunity to interrogate the respondent's narration and also to inquire on topics or subjects that the respondent did not discuss. As the third sub-session is somewhat reactionary, the composition of the interview is left to the interviewer's discretion. In some instances the third sub-session is not conducted.

6.4 The explicit role or application of theory, in this form of biographical interview, may not be immediately accepted or clear. Merrill and West (2009: 184-185), commenting on the role of theory in biographical research suggest its application can be found in data analysis. For these authors, theory in this context is: 'middle range and experimentally driven' (2009: 184). Faraday and Plummer (2005) discuss the rift in the biographical community in regards to the place of theory in the biographical interview. They contend that theory can produce direction as results can question theory. Miller (2000) discusses the various forms of the biographical interview: the realist, the narrative and the neo-positivist. The key difference in each being the role that theory plays in data collection and analysis. His ideal types span from a highly inductive approach to a hypothesis testing deductive approach. It is the deductive, neo-positivist biographical approach, when applied to Schütze's biographical narrative interview that is most appropriate to address Bourdieu's epistemological challenge.

6.5 The neo-positivist biographical narrative interview is a theoretically influenced approach. It is this application of theory that will provide the researcher the opportunity to break away from a common sense understanding of the social phenomenon in which they are interested, as social theory allows us to question social relations in a critical manner, creating the opportunity for an epistemological break. Theory will play a role not solely in the problématique, but also in the design; the research sample, the initial narrative question and subsequent questions. From this, the neo-positivist biographical approach is widely understood to be the least fluid or the most deterministic. However, the technical constraints of the interview still apply. The interviewer is compelled to conduct two sub-sessions in which they have very little opportunity to influence the respondent, whilst their questions may be influenced by theory, the initial narrative question must be clear that the respondent can discuss anything they wish to, as it is their life hi/story. In the second sub-session, the researcher can only ask questions concerning what the respondent has discussed, the questions cannot be leading. It is only in the third sub-session that an overt application of theory should be evident. It is from the technical constraints of the interview that radical doubt towards theoretical or learned bias can be practiced, as it forces researchers to consider narratives or topics that their theoretical background or influence would perhaps have not considered or pursued.

6.6 The analysis of the empirical findings will also be influenced by social theory. The interpenetrative relationship between theory and empiricism can provide an opportunity for radical doubt towards theoretical bias in the analysis, when theory is applied through "grounded" data, adaptations, extensions or even cessation of certain theoretical understandings may be appropriate, providing an opportunity for radical doubt. Miller when writing on the neo-positivist biographical approach, comments, "in [this] approach, after deducing, one must induce' (2000: 15). It is this form of grounded approach, which Reay (2004) argues can offer a fuller understanding from a Bourdieusian perspective. We can use pre-existing theory along with grounded data to develop a more nuanced progression of our theory. The theory and data constantly challenge and reinforce each other. It is this dynamic relationship which was the intention of the empirical application of the habitus.

\section{The Empirical Context: putting theory, and method, to work}

7.1 At times this paper has offered quite an abstract discussion concerning epistemological challenges. It could be applied to many sub-disciplines of sociology, not solely to the sociology of education. This paper is in part an effort to resist the temptation to box off sub-disciplines - a theory or method that "caters for one", the pre-occupation with offering an argument or stance so specific or narrow, it could damage the principals this paper has attempted to defend. As Bourdieu and Wacquant argue, 'we must be aware of all sectarian dismissals which hide behind excessively exclusive professions of faith' (1992: 227). This sectarianism is evident between theory and empiricism, in the context of educational research. Hammersley (2006) discusses the problematic fashion in which educational sociologists have approached philosophy in their research, suggesting that philosophy has either been abstracted to the extent that objectivity is impossible to attain or has been ignored to the effect that empirical research is understood as a technical practice. Hammersley argues this creates a barrier between research and philosophy sterilising the social world that is being studied whilst taking for granted previous philosophical understandings. Hammersley suggests that understanding 'methodology-as-philosophy' (2006: 278) will offer a resource to allow us to question previous assertions and offer a broader range of positions that will allow for a deeper understanding of the educational problematique. This can be achieved, by not only providing latitude within theoretical discourses but also by allowing more than theoretical discourses to be discussed. The neopositivist biographical narrative interview can offer an opportunity to do this.

7.2 Biographical or life hi/story research has become increasingly popular in educational research. It has been applied to lifelong learning research (Brooks 2006), educational transitions (Brooks and Everett 2009) and research on low undergraduate retention levels (Page 1998). Mann (1998) applied biographical research methods when looking at the educational choices made by adolescent girls. However, Mann's research did not solely look at the school his respondents attended, but also the educational history of the respondents and their parents. The research also attempted to take into consideration the wider social context in terms of apparent changing gender norms and class identity. Ward and Jenkins (1999), writing on their application of life stories to assess graduate's educational experiences, comment that whilst a great deal money and 
time had been spent in the 1990s on assessing higher education within the United Kingdom little was known about the individual student experience. The authors write:

All of these [previous studies] have a part to play, and we acknowledge their usefulness, but they fail to address our main question: What is the long-term impact (if any) of a degree on the individual lives of a representative group of graduates? This is where the oral historian comes in. Take a look around... (1999: 86)

7.3 Foster et al. (1996) charting the historical progression of educational research, argue it was through a shift from a psychological to a sociological gaze that lead to the understanding that social inequalities were fostered through academic selection processes, and not through an inherited familial social disadvantage. Foster et al. highlight the continuing need for a critical sociological approach to educational inequalities. It would be arrogant for us to question previous understandings and then to not continuously question ourselves. Foster et al. (1996: 3) explain, during the Thatcher administration, educational research concerned with social inequalities (Hargreaves 1967) or social friction felt by working classes (Jackson and Marsden 1966) was replaced by a preoccupation of academic standards and test scores. Clearly the danger of a preoccupation with declining academic standards without an appreciation of inequality within the educational system - is that the blame for failure is placed on the individual and not the system.

\section{Conclusion}

8.1 This paper has been a reflection on my own empirical processes and epistemological stance. Reading Bourdieu et al's. comments, 'all the techniques of objectification have to be applied in order to achieve a break that is more often proclaimed than performed' (1991: 13), has forced me to contemplate whether this paper is a sermon of empty rhetoric, or whether it is a useful and practical comment on my own theoretical and empirical challenges and how I have attempted to address them.

8.2 Through this paper I have attempted to discuss the place, or role, of social theory within empirical research, contending that it is an unavoidable necessity and that through appropriate application and safeguarding, it can lead to greater insights into the social world. I have discussed how Bourdieu's concept of habitus, as an empirical tool, is respectful of the interpenetrative relationship between theory and empiricism. I have also attempted to demonstrate how the neo-positivist biographical narrative interview, as a form of data collection, allows this process to happen through an application of theory, providing an epistemological break with common sense and a respect for "grounded" data that may challenge our preconstructed theoretical concepts.

8.3 In an effort to move beyond the binary triumph/failure of the individual, I have demonstrated how educational research, and the "sectarian" divide within it, requires this approach to effectively address issues with a sociological gaze. The pre-occupation with academic standards and test scores that Foster et al (1996) charted during the Thatcher administration continues today, as the educational system continues to be a source of the reproduction of social inequality. Without the application of social theory, we may be inclined to understand the processes of social inequality as a trouble and fail to recognise it as an issue (Mills 1959).

\section{Acknowledgements}

I would like to thank the two anonymous referees and the journal editors for their constructive comments on an earlier draft of this article.

This paper was originally drafted for an ESRC Research Methods workshop, organised and delivered by Prof. Derek Robbins and Dr. Tim Jenkins entitled "The Epistemology of the Social Sciences." It was through the comments and guidance from the organisers and fellow participants that this article grew into its current form. I would like to take the opportunity to thank them. I would like to extend a special thanks to Tamsin Bowers-Brown and Paul Doran for their insightful comments, and kind track changes, on a much later version of this paper.

\section{References}

APITZSCH, U. and Inowlocki, L. (2005) "Biographical Analysis: A “German" School?" In: Miller, R.L. (ed.) Biographical Research Methods Volume III. London: Sage Publications. pp. 5-24.

ATKINSON, R. (1998) The Life Story Interview. London: Sage Publications

BALL, S.J. (1995) "Intellectuals of Technicians? The Urgent Role of Theory in Educational Studies", British Journal of Educational Studies, vol. 43 (3), pp. 255-271.

BALL, S.J., Maguire, M. and Macrae, S. (2000). Choices, Pathways and Transitions Post-16: New Youth, New Economy in the Global City. London: Routledge Falmer.

BOURDIEU, P. (1977) Outline of a Theory of Practice. Cambridge: Cambridge University Press.

BOURDIEU, P. (1984) Distinction: A Social Critique of the Judgement of Taste . London: Routledge and Kegan Paul.

BOURDIEU, P. (1987) "The Biographical Illusion", Working Papers and Proceedings of the Centre for Psychosocial Studies, vol. 14, pp. 1-7. 
BOURDIEU, P. (1988) Homo Academicus. Oxford: Polity Press.

BOURDIEU, P. (2004) "The Forms of Capital” In: Ball, S. (ed.) Routledge Falmer Reader in Sociology of Education. Abingdon: Routledge Falmer. pp. 15-29.

BOURDIEU, P. (2007) Sketch for a Self-Analysis. Cambridge: Polity Press.

BOURDIEU, P. and Boltanski, L. (1978) "Changes in Social Structure and Changes in Demand for Education", In: Ginger, S. and Archer, M.S. (eds.) Contemporary Europe: Social Structures and Cultural Patterns. London: Routledge and Kegan Paul. pp. 197- 227.

BOURDIEU, P., Chamboredon, J-C. and PASSERON, J-C. (1991) The Craft of Sociology : Epistemological Preliminaries. New York: Walter de Gruyter.

BOURDIEU, P. and Passeron, J-C. (1990) Reproduction in Education Society and Culture. $2^{\text {nd }}$ ed. London: Sage Publications.

BOURDIEU, P. and Wacquant, L.J.D (1992) An Invitation to Reflexive Sociology. Cambridge: Polity Press.

BROOKS, R. (2006) "Young Graduates and Lifelong Learning: The Impact of Institutional Stratification", Sociology, vol. 40 (6), pp. 1019-1037. [doi:10.1177/0038038506069842]

BROOKS, R. and Everett, G. (2009) "Post-Graduation Reflections on the Value of a Degree", British Educational Research Journal, vol. 35 (3), pp. 333-349. [doi:10.1080/01411920802044370]

CARR, W. (2000) "Partisanship in Educational Research", Oxford Review of Education, vol. 26 (3), pp. 437449. [doi:10.1080/713688539]

DEEM, R. (2002) "Talking to Manager-Academics: Methodological Dilemmas and Feminist Research Strategies", Sociology 36 (4), pp. 835-855. [doi:10.1177/003803850203600403]

DU BOIS, B. (1983) "Passionate Scholarship: Notes on Values, Knowing and Method in Feminist Social Science" In: Bowles, G. And Klein, R.D. (eds.) Theories of Women's Studies, London: Routledge and Kegan Paul, pp. 105-116.

ELLIOTT, B. (2005) "Biography, Family History and the Analysis of Social Change", In: Miller, R.L. (ed.) Biographical Research Methods Volume III. London: Sage Publications. pp. 303-324.

ERBEN, M. (1998) "Biography and Research Method" In: Erben, M. (ed.) Biography and Education: A Reader. London: Falmer Press. pp. 4-17.

FARADAY, A. and Plummer, K. (2005) "Doing Life Histories" In: Miller, R.L. (ed.) Biographical Research Methods Volume IV. London: Sage Publications. pp. 249-274.

FOSTER, P., Gomm, R. and Hammersley, M. (1996) Constructing Educational Inequality: An Assessment of Research on School Processes. London: Falmer Press.

GLASER, B.G. and Strauss, A.L. (1967) The Discovery of Grounded Theory. Aldine Publishing Company: New York.

GRENFELL, M. and James, D. (1998) "Theory, Practice and Pedagogic Research" In: Grenfell, M. and James, D. (eds.) Bourdieu and Education: Acts of Practical Theory. Abingdon: RoutledgeFalmer. pp. 6-26.

HAMMERSLEY, M. (1992) "On Feminist Methodology", Sociology 26 (2), 187-206.

[doi:10.1177/0038038592026002002]

HAMMERSLEY, M. (2006) "Philosophy's Contribution to Social Science Research on Education", Journal of Philosophy of Education, vol. 40 (2), pp. 273-286. [doi:10.1111/j.1467-9752.2006.00504.x]

HAMMERSLEY, M. (2008) Questioning Qualitative Inquiry: Critical Essays. London: Sage Publications.

HARGREAVES, D.H. (1967) Social Relations in a Secondary School. London: Routledge and Kegan Paul. [doi:10.4324/9780203001837]

HEATH, H. and Cowley. (2004) "Developing a Grounded Theory Approach: A Comparison of Glaser and Strauss", International Journal of Nursing Studies, vol. 41, pp. 141-150. [doi:10.1016/S0020-7489(03)001135]

HOLLOWAY, W. and Jefferson, T. (2000) "Biography, Anxiety and the Experience of Locality", In: Chamberlayne, P., Bornat, J and Wengraf, T. (eds.) The Turn to Biographical Methods in Social Science. London: Taylor \& Francis Ltd. pp. 167-180.

JACKSON, B. and Marsden, D. (1966) Education and the Working Classes. Middlesex: Pelican books. JENKINS, R. (2002) Pierre Bourdieu: Revised Edition. London: Routledge.

KLEIN, R.D. (1983) "How to Do What We Want to Do: Thoughts on Feminist Methodology" In: Bowles, G. 
And Klein, R.D. (eds.) Theories of Women's Studies, London: Routledge and Kegan Paul, pp.88-104. .

LAHIRE, B. (2003) "From the Habitus to an Individual Heritage of Dispositions. Towards a Sociology at the Level of the Individual", Poetics, vol. 31 (1), pp. 329-355. [doi:10.1016/j.poetic.2003.08.002]

MANN, C. (1998) "Adolescent Girls Reflect on Educational Choices" In: Erben, M. (ed.) Biography and Education: A Reader. London: Falmer Press. pp. 46-58.

MERRILL, B. and West, L. (2009) Using Biographical Methods in Social Research. London: Sage Publications.

MILLER, R. L. (2000) Researching Life Stories and Family Histories. London: Sage Publications.

MILLER, R.L., Humphrey, R. and Zdravomyslova, E. (2005) "Biographical Research and Historical Watersheds", In: Miller, R.L. (ed.) Biographical Research Methods Volume I. London: Sage Publications. pp. 113-132.

MILLS, C.W. (1959) The Sociological Imagination. Oxford: Oxford University Press.

NASH, R. (1999) "Bourdieu, 'Habitus', and Educational Research: Is it All Worth the Candle?", British Journal of Sociology of Education, vol. 20 (2), pp. 175-187. [doi:10.1080/01425699995399]

OAKLEY, A. (1981) "Interviewing Women: A Contradiction in Terms" In: Roberts, H. (ed.) Doing Feminist Research. London: Routledge and Kegan Paul, pp. 30-62.

PAGE, M. (1998) "Collecting Slices of College Dropouts' Lives" In: Erben, M. (ed.) Biography and Education: A Reader. London: Falmer Press. pp. 88-102.

REAY. D. (1998) "Cultural Reproduction: Mother's Involvement in Their Children's Primary Schooling" In: Grenfell, M. And James, D. (eds.) Bourdieu and Education: Acts of Practical Theory. Abingdon: RoutledgeFalmer. pp. 55-71.

REAY, D. (2000) "Rethinking Social Class Qualitative Perspectives on Class and Gender", In: Ball, S.J. (ed.) Sociology of Education: Major Themes vol. 2. London: Routledge. pp. 990-1008.

REAY, D. (2004) "It's All Becoming a Habitus: Beyond the Habitual Use of Habitus in Educational Research", British Journal of Sociology of Education, vol. 25 (4), pp. 431-444.

[doi:10.1080/0142569042000236934]

REAY. D., Crozier, G. and Clayton, J. (2010) “'Fitting in' or 'Standing Out': Working-class Students un UK Higher Education System”, British Educational Research Journal, vol. 36 (1), pp. 107-124.

[doi:10.1080/01411920902878925]

REAY, D., David, M. and Ball, S. (2005) Degrees of Choice: Social Class, Race and Gender in Higher Education. Stoke on Trent: Trentham Books.

ROBBINS, D. (1998) “The Need for an Epistemological 'Break'” In: Grenfell, M. and James, D. (eds.) Bourdieu and Education: Acts of Practical Theory. Abingdon: RoutledgeFalmer . pp. 27-51.

ROSENTHAL, G. (2003) "The Healing Effects of Storytelling: On the Conditions of Curative Storytelling in the Context of Research and Counselling", Qualitative Inquiry, vol. 9 (6), pp. 915-933.

[doi:10.1177/1077800403254888]

ROSENTHAL, G. (2005) "Biographical Research" In: Miller, R.L. (ed.) Biographical Research Methods Volume III. London: Sage Publications. pp. 25-58.

SCHÜTZE, F. (1992) "Pressure and Guilt: The Experience of a Young German Solider in World War Two and its Biographical Implications", International Sociology, vol. 7 (2), pp. 187-208; vol. 7 (3), pp. 347-367.

SCHÜTZE, F. (2008) Biography Analysis on the Empirical Base of Autobiographical Narratives: How to Analyse Autobiographical Narrative Interviews - Part I (online) Available at $<$ http://www.biographicalcounselling.com/download/B2.1.pdf>

SEGERT, A. and Zierke, I. (2000) "The Metamorphosis of Habitus among East Germans", In: Chamberlayne, P., Bornat, $J$ and Wengraf, $T$. (eds.) The Turn to Biographical Methods in Social Science. London: Taylor \& Francis Ltd. pp. 229-243.

STANLEY, L. And Wise, S. (1990) "Method, Methodology and Epistemology in Feminist Research Processes" In: Stanley, L. (ed.) Feminist Praxis: Research, Theory and Epistemology in Feminist Sociology. London: Routeledge, pp. 20-62.

WACQUANT, L.J.D (1993) "Bourdieu in America: Notes on the Transatlantic Importation of Social Theory", In: Calhoun, C, LiPuma, E. and Postone, M. (eds.) Bourdieu: Critical Perspectives. Oxford: Polity Press. pp. 235-262.

WARD, A. and Jenkins, A. (1999) "Collecting the Life-Stories of Graduates: Evaluating Students' Educational Experiences", Oral History, vol. 27 (2), pp. 77-86. 
